\title{
Diversity and extracellular enzymatic activities of yeasts isolated from King George Island, the sub- Antarctic region
}

Mario Carrasco, Juan Manuel Rozas, Salvador Barahona, Jennifer Alcaíno, Víctor Cifuentes and Marcelo Baeza*

\begin{abstract}
Background: Antarctica has been successfully colonized by microorganisms despite presenting adverse conditions for life such as low temperatures, high solar radiation, low nutrient availability and dryness. Although these "cold-loving" microorganisms are recognized as primarily responsible for nutrient and organic matter recycling/ mineralization, the yeasts, in particular, remain poorly characterized and understood. The aim of this work was to study the yeast microbiota in soil and water samples collected on King George Island.

Results: A high number of yeast isolates was obtained from 34 soil and 14 water samples. Molecular analyses based on rDNA sequences revealed 22 yeast species belonging to 12 genera, with Mrakia and Cryptococcus genera containing the highest species diversity. The species Sporidiobolus salmonicolor was by far the most ubiquitous, being identified in 24 isolates from 13 different samples. Most of the yeasts were psychrotolerant and ranged widely in their ability to assimilate carbon sources (consuming from 1 to 27 of the 29 carbon sources tested). All species displayed at least 1 of the 8 extracellular enzyme activities tested. Lipase, amylase and esterase activity dominated, while chitinase and xylanase were less common. Two yeasts identified as Leuconeurospora sp. and Dioszegia fristingensis displayed 6 enzyme activities.

Conclusions: A high diversity of yeasts was isolated in this work including undescribed species and species not previously isolated from the Antarctic region, including Wickerhamomyces anomalus, which has not been isolated from cold regions in general. The diversity of extracellular enzyme activities, and hence the variety of compounds that the yeasts may degrade or transform, suggests an important nutrient recycling role of microorganisms in this region. These yeasts are of potential use in industrial applications requiring high enzyme activities at low temperatures.
\end{abstract}

Keywords: Antarctic yeasts, Psychrophilic-psychrotolerant yeasts, Extracellular enzyme activities, rDNA yeast identification

\section{Background}

Permanently cold environments are widely distributed on Earth, and include the Polar Regions, mountains and deep-sea environments. Despite presenting adverse conditions for life, such as freezing temperatures, low nutrient availability, high water viscosity and reduced membrane fluidity, these environments have been successfully colonized by the three domains of life [1]. Cold-adapted microorganisms can grow at $0^{\circ} \mathrm{C}$ and are

\footnotetext{
* Correspondence: mbaeza@u.uchile.cl

Laboratorio de Genética, Depto. de Ciencias Ecológicas, Facultad de Ciencias, Universidad de Chile, Las Palmeras 3425 Casilla, Santiago 653, Chile
}

classified as psychrophilic if their optimum and maximum temperatures for growth are $\leq 15^{\circ} \mathrm{C}$ and $\leq 20$, respectively, or as psychrotolerant (psychrotrophic) if their maximum temperature for growth is above $20^{\circ} \mathrm{C}[2,3]$. Such microorganisms have adapted their vital cellular processes to thrive in cold environments [4]. They make essential contributions to nutrient recycling and organic matter mineralization, via a special class of extracellular enzymes known as "cold-adapted" or "cold-active" enzymes [5]. Because these enzymes have a higher catalytic efficiency than their mesophilic counterparts at temperatures below $20^{\circ} \mathrm{C}$ and display unusual substrate specificities, they are attractive candidates for industrial

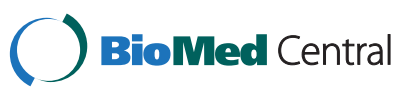


processes requiring high enzymatic activity at low temperatures. Cold-adapted enzymes include amylase, cellulase, invertase, inulinase, protease, lipase and isomerase, which are used in the food, biofuel and detergent industries [6]. Largely because of their potential in biotechnological applications, cold-adapted microorganisms have become increasingly studied in recent years, yet remain poorly understood. Of the microorganisms most isolated and studied from cold environments, the majority are bacteria, while yeasts constitute a minor proportion [1].

Antarctica is considered the coldest and driest terrestrial habitat on Earth. It is covered almost totally with ice and snow, and receives high levels of solar radiation [7]. The Sub-Antarctic region, including the Shetland South Archipelago, has warmer temperatures, the soils close to the sea are free of snow/ice and receive significant quantities of organic material from marine animals; however, they are subject to continuous and rapid freethaw cycles, which are stressful and restrictive to life [8]. Although the first report of Antarctic yeasts was published 50 years ago [9] current reports have focused on cold-tolerant Bacteria and Archaea, with yeasts receiving less attention. Yeasts dwelling in Antarctic and SubAntarctic maritime and terrestrial habitats belong mainly to the Cryptococcus, Mrakia, Candida and Rhodotorula genera [10-12]. In a recent work, $43 \%$ of Antarctic yeast isolates were assigned to undescribed species [13], reflecting the lack of knowledge regarding cultivable yeasts that colonize the Antarctic soils. Yet these organisms constitute a valuable resource for ecological and applied studies.

This work describes the isolation of yeasts from terrestrial habitats of King George Island, the major island of the Shetland South archipelago. The yeast isolates were characterized physiologically and identified at the molecular level using the D1/D2 and ITS1-5.8S-ITS2 regions of rDNA. In addition, the ability of the yeasts to degrade simple or complex carbon sources was evaluated by analyzing their extracellular hydrolytic enzyme activities. Characterizing these enzyme activities may enhance the potential of the yeasts in industrial applications.

\section{Results}

\section{Isolation of psychrophilic and psychrotolerant yeasts}

The 34 soil and 14 water samples obtained from different areas of King George Island were processed as described in the Methods section. The suspensions obtained from each soil samples were seeded onto nutritive plates, and incubated in triplicate over a range of temperatures $\left(4,10,15\right.$ and $\left.22^{\circ} \mathrm{C}\right)$. After $30-90$ days of incubation, approximately 30 to 60 yeast-like colonies developed on each plate. In contrast, no colonies or low colony numbers (4 to 8 ) appeared on plates from water samples. Because large numbers of isolates were obtained, isolates were grouped according to their isolation growth temperature and colony characteristics such as pigmentation, texture, elevation and size. Among the 64 groups, several differed only by isolation growth temperature. These isolates were grown at different temperatures and re-grouped according to macromorphological characteristics at their optimal growth temperature. In this way, 35 groups were ultimately generated. Several isolates from each group (at least one isolate per sampling site; a total of 78 isolates) were selected for molecular and biochemical analyses.

\section{Molecular identification of yeasts}

The chromosomal DNA was purified from cultures of each yeast isolate and the D1/D2 region of $26 \mathrm{~S}$ rDNA and the ITS1-5.8S- ITS2 (hereafter designated the ITS region for simplicity) regions of the rDNA were amplified by PCR. The amplicons obtained were purified from gels and sequenced on both strands. Isolates showing $100 \%$ identity in both rDNA sequences were grouped and their DNA sequences were submitted to GenBank under the accession numbers listed in Table 1. Species identification was performed by comparison with the GenBank references, using as criterion the Blast-hits with $\leq 0.5 \%$ difference with the query [14]. In $84 \%$ of the isolates the closest Blast-hits obtained for both rDNA sequences were coincident. When this was not the case, the D1/D2 results were used for identification because they yielded higher identity percentages than did the ITS (see Additional file 1). $76 \%$ of the isolates could be identified to species level by this molecular analysis. 22 species belonging to12 genera were identified, of which 80 and $20 \%$ were Basidiomycetes and Ascomycetes, respectively. The genera containing the highest number of species were Mrakia (5 species) and Cryptococcus (4 species). However, the species Sporidiobolus salmonicolor was the most abundant, being identified in 24 isolates from 13 different sampling sites. Mrakia gelida was the only yeast species present in both water and soil samples. Of the three isolates identified as Leuconeurospora sp., two of them (T11Cd2 and $\mathrm{T} 27 \mathrm{Cd} 2)$ possessed identical D1/D2 and ITS sequences, both of which differed from the third (T17Cd1) by $0.7 \%$. However, the macromorphological characteristics of the three isolates, including pigmentation, differed markedly under identical culture conditions (see Additional file 2). Because of these discrepancies, the molecular and morphological analyses were repeated several times, but the results were highly consistent. The carbon source assimilation pattern also differed between the isolates, as will be discussed later. 
Table 1 Molecular identification of yeast isolates

\begin{tabular}{|c|c|c|c|c|c|}
\hline \multirow[t]{2}{*}{ Sample } & \multicolumn{2}{|c|}{ ITS1-5.8S-ITS2 } & \multicolumn{2}{|l|}{ D1/D2 } & \multirow[t]{2}{*}{ Identification } \\
\hline & Accession & Closest match & Accession & Closest match & \\
\hline sea water & JQ857022 & Candia sake (AJ549822) & JQ856998 & Candida sake (AJ507662) & Candida sake \\
\hline soil & JQ857023 & Cryptococcus terricola (FN298664) & JQ856999 & Cryptococcus terricola (AM039670) & Cryptococcus sp. \\
\hline soil & JQ857024 & Cryptococcus gastricus (AF145323) & JQ857000 & Cryptococcus gastricus (AF137600) & Cryptococcus gastricus \\
\hline soil & JQ857026 & Metschnikowia australis (JN197598) & JQ857002 & Metschnikowia australis (U76526) & Metschnikowia sp \\
\hline soil & JQ857027 & Mrakia robertii (AY038829) & JQ857003 & Mrakia robertii (EF643726) & Mrakia robertii \\
\hline soil & JQ857028 & Mrakia blollopis (AY038828) & JQ857004 & Mrakia blollopis (AY038828) & Mrakia blollopis \\
\hline soil & JQ857031 & Cryptococcus watticus (FJ473373) & JQ857007 & Holtermanniella watticus (FJ748666) & Holtermanniella watticus \\
\hline soil & JQ857033 & Dioszegia crocea (AF444406) & JQ857009 & Dioszegia crocea (HQ256888) & Dioszegia sp \\
\hline soil & JQ857034 & Leucosporidium drummii (FN908919) & JQ857010 & Leucosporidiella fragaria (DQ513270) & Leucosporidiella fragaria \\
\hline \multirow[t]{2}{*}{ soil } & JQ857038 & Dioszegia fristingensis (EU070927) & JQ857014 & Dioszegia fristingensis (JN400789) & Dioszegia fristingensis \\
\hline & JQ857039 & Dioszegia fristingensis (EU070927) & JQ857014 & Dioszegia fristingensis (JN400789) & Dioszegia fristingensis \\
\hline soil & JQ857025 & Cryptococcus victoriae (HQ717406) & JQ857001 & Cryptococcus victoriae (JN544032) & Cryptococcus victoriae \\
\hline soil & JQ857032 & Rhodotorula glacialis (EF151250) & JQ857008 & Rhodotorula glacialis (EF643741) & Rhodotorula glacialis \\
\hline \multirow[t]{2}{*}{ soil } & JQ857035 & Mrakia gelida (AF144485) & JQ857011 & Mrakia robertii (EF643731) & Mrakia sp. \\
\hline & & & & Mrakia frigida (DQ513285) & \\
\hline $\begin{array}{l}\text { melt water, } \\
\text { soil }\end{array}$ & JQ857036 & Mrakia gelida (GQ911545) & JQ857012 & Mrakia gelida (GQ911518) & Mrakia gelida \\
\hline soil & JQ857037 & Rhodotorula glacialis (EF151250) & JQ857013 & Rhodotorula glacialis (AB671326) & Rhodotorula glacialis \\
\hline soil & JQ857040 & Pseudeurotium bakeri (GU934582) & JQ857015 & $\begin{array}{l}\text { Leuconeurospora pulcherrima } \\
\text { (FJ176884) }\end{array}$ & Leuconeurospora sp. \\
\hline soil & JQ857041 & Pseudeurotium bakeri (GU934582) & JQ857016 & $\begin{array}{l}\text { Leuconeurospora pulcherrima } \\
\text { (FJ176884) }\end{array}$ & Leuconeurospora sp. \\
\hline melt water & JQ857021 & $\begin{array}{l}\text { Wickerhamomyces anomalus } \\
\text { (JF416789) }\end{array}$ & JQ856997 & $\begin{array}{l}\text { Wickerhamomyces anomalus } \\
\text { (JN180956) }\end{array}$ & $\begin{array}{l}\text { Wickerhamomyces } \\
\text { anomalus }\end{array}$ \\
\hline soil & JQ857030 & Cryptococcus gilvescens (AF444380) & JQ857006 & Cryptococcus gilvescens (EF643719) & Cryptococcus gilvescens \\
\hline soil & JQ857018 & Mrakia psychrophila (EU224267) & JQ856994 & Mrakia psychrophila (EU224266) & Mrakia psychrophila \\
\hline soil & JQ857029 & Rhodotorula laryngis (AB078500) & JQ857005 & Rhodotorula laryngis (DQ640477) & Rhodotorula laryngis \\
\hline soil & JQ857017 & Glaciozyma antarctica (AY033637) & JQ856993 & Glaciozyma antarctica (AY040642) & Glaciozyma antarctica \\
\hline soil & JQ857019 & $\begin{array}{l}\text { Leucosporidiella creatinivora } \\
\text { (AF444629) }\end{array}$ & JQ856995 & Leucosporidiella creatinivora (AF189925) & Leucosporidiella creatinivora \\
\hline soil & JQ857020 & Sporidiobolus salmonicolor (AF444611) & JQ856996 & Sporidiobolus salmonicolor (EU596439) & Sporidiobolus salmonicolor \\
\hline
\end{tabular}

\section{Physiological characteristics and extracellular enzyme activities}

The isolates were grown at six temperatures (range 4 to $37^{\circ} \mathrm{C}$ ). Almost $70 \%$ of the yeast isolates could grow at $22^{\circ} \mathrm{C}$ or higher, and generally grew optimally at $15^{\circ} \mathrm{C}$ $(38 \%)$ or $22^{\circ} \mathrm{C}(31 \%)$ (Table 2). These results were accounted for in the physiological characterizations of the strains. The isolates identified as Candida sake, Wickerhamomyces anomalus and the four Mrakia species, tested positive in glucose fermentation assays. The yeast isolates were tested for the assimilation of 29 different carbon sources (for the detailed results see Additional file 3). Besides glucose, the yeasts primarily consumed D-xylose, D-melezitose, D-saccharose, Dtrehalose and 2-ketogluconate, while lactose, levulinic acid and erythritol were less assimilated. Some yeasts could assimilate glucose alone (Glaciozyma antarctica, formerly Leucosporidium antarcticum), but others assimilated as many as 27 carbon sources (Cryptococcus victoriae and Mrakia sp.). The assimilation tests were performed for the isolates obtained from different sampling sites and identified molecularly as the same yeast species, with concordant results in most cases. However, the two isolates identified as Mrakia psychrophila differed in their assimilation of rhamnose and in the esculin test, while three isolates identified as Leuconeurospora sp., two of which were identical at molecular level, differed significantly in their utilization of seven carbon sources. For those isolates that were molecularly identified to genera level only, the carbon assimilation profiles supported their differentiation from the closest Blast-hits in each case: Cryptococcus sp. differed from Cr. terricola (98.2\% identity) in the assimilation of L-arabinose, trehalose, lactose, L-rhamnnose, 
Table 2 Growth temperatures and extracellular enzyme activities of yeast isolates

\begin{tabular}{|c|c|c|c|c|c|c|c|c|c|}
\hline \multirow[t]{2}{*}{ Yeast species } & \multirow{2}{*}{$\begin{array}{l}\text { Temp. } \\
{ }^{\circ} \mathrm{C}\end{array}$} & \multicolumn{8}{|c|}{ Enzyme activities halo $\left(\mathrm{mm}^{*}\right)$} \\
\hline & & Ami & Cel & Est & Lip & Pro & Pec & Chi & $\mathrm{Xyl}$ \\
\hline C. sake & $4-22(22)$ & - & - & - & 1 & - & - & - & - \\
\hline Cr. gastricus & $4-22(22)$ & 2 & 1 & 2 & 1 & - & - & - & - \\
\hline Cr. gilvescens & $4-22(22)$ & 2 & - & - & 1 & 1 & - & - & - \\
\hline Cr. victoriae & 4-15 (15) & - & 4 & 5 & 2 & - & - & - & - \\
\hline Cryptococcus sp. & $4-22(15)$ & 2 & - & - & 1 & 1 & - & - & - \\
\hline D. fristingensis (T11Df) & $4-22(22)$ & 7 & 4 & - & 1 & - & 7 & 2 & 3 \\
\hline D. fristingensis (T9Df1) & $4-22(22)$ & 3 & - & 6 & 1 & - & - & - & - \\
\hline Dioszegia sp. & 4-15 (15) & 7 & - & 6 & - & - & 6 & - & - \\
\hline G. antarctica & 4-15 (10) & - & - & 2 & - & - & - & - & - \\
\hline H. watticus & $4-37(30)$ & 2 & 2 & - & - & - & - & - & - \\
\hline Le. creatinivora & 4-22 (22) & - & - & 3 & 1 & - & - & - & - \\
\hline Le. fragaria & $4-22(22)$ & - & 2 & 2 & 1 & - & 3 & - & - \\
\hline Leuconeurospora sp. (T11Cd2) & 4-22(15) & 2 & - & 6 & - & - & - & - & - \\
\hline Leuconeurospora sp. (T17Cd1) & $4-22(15)$ & - & 4 & 3 & 2 & 1 & 6 & 2 & - \\
\hline Leuconeurospora sp. (T27Cd2) & 4-22 (15) & - & 2 & 2 & 1 & 1 & - & 2 & - \\
\hline M. blollopis & 4-22 (15) & 1 & 8 & 3 & - & - & - & - & - \\
\hline M. gelida & 4-15 (10) & 2 & 2 & - & 1 & 2 & - & - & - \\
\hline M. psychrophila & 4-15 (10) & - & 10 & 7 & - & - & 3 & 1 & - \\
\hline M. robertii & 4-15 (15) & 2 & 2 & - & 1 & - & 3 & - & - \\
\hline Metschnikowia sp. & $4-22(10)$ & - & - & - & 1 & - & 2 & 1 & - \\
\hline Mrakia sp. & 4-15 (15) & 2 & 2 & - & 1 & - & - & - & - \\
\hline Rh. glacialis & 4-15 (15) & 2 & - & 2 & 1 & - & 1 & - & - \\
\hline Rh. glacialis & $4-22(10)$ & 2 & - & - & 1 & - & 2 & - & - \\
\hline Rh. laryngis & 4-30 (30) & - & - & 4 & 2 & - & 2 & - & - \\
\hline Sp. salmonicolor & 4-30 (22) & - & - & - & 2 & 1 & 6 & 2 & - \\
\hline W. anomalus & $4-37(30)$ & - & 1 & 2 & 2 & 5 & 3 & - & - \\
\hline
\end{tabular}

L-sorbose and glucosamine; Mrakia $s p$. differed from M. frigida (99.7\% identity) in the assimilation of maltose, ribose, erythritol and glucosamine, and from $M$. robertii (99.7\% identity) in the assimilation of glycerol and erythritol; Dioszegia $s p$. differed from D. crocea (99.3\% identity) in assimilation of raffinose, mellibiose and glycerol.

To estimate the ability of the yeasts to utilize nutrients in their natural environment, they were initially characterized for the production of 8 extracellular enzyme activities. As shown in Table 2, all yeasts displayed at least one enzyme activity, which further enhances their potential for biotechnological/industrial exploitation. The majority exhibited 2 to 4 enzyme activities, while two exceptional isolates exhibited 6 enzyme activities: Leuconeurospora sp. (T17Cd1) (cellulase, esterase, lipase, protease, pectinase and chitinase) and Dioszegia fristingensis (T11Df) (amylase, cellulase, lipase, pectinase, chitinase, and xylanase). The most common enzyme activities in the yeast isolates were esterase and lipase, while the least common was xylanase, demonstrated only by $D$. fristingensis. The three isolates molecularly identified as Leuconeurospora sp. (T17Cd1, T11Cd2 and $\mathrm{T} 27 \mathrm{Cd} 2$ ) showed important differences in their enzyme activities, as was also observed in the isolates identified as D. fristingensis (T9Df1 and T11Df).

\section{Discussion}

Approximately $70 \%$ of the isolated yeasts could grow at temperatures above $20^{\circ} \mathrm{C}$, and $16 \%$ of them were able to grow at $\geq 30^{\circ} \mathrm{C}$. The predominance of psychrotolerant fungi in cold environments has been previously noted, and is attributable to seasonal and local increases in soil temperature due to solar radiation [2]. In our study, the temperature measured in situ at the different sampling sites ranged from 0 to $11.9^{\circ} \mathrm{C}$, but temperatures up to $20^{\circ} \mathrm{C}$ have been reported in this region [15-17]. The main obstacle to assessing the yeast communities in 
Antarctic regions is the scant knowledge regarding their environmental and nutritional requirements. Because the yeast populations/species inhabiting terrestrial and aquatic environments can colonize specific niches, no appropriate method exists for efficiently isolating all species [18]. In this work the yeasts were isolated using rich media supplemented with glucose, because almost all known yeasts can assimilate this sugar [19]. However, this culture condition could favor the proliferation of yeasts with high metabolic rates, to the detriment of slow-growing yeasts. Nevertheless, large numbers and high species diversity were attained in this study (22 species from 12 genera). Cold-loving yeasts have been isolated mainly from the Antarctic and the Arctic, and from European and South American glaciers [10]. In all of these environments, the most ubiquitous species are Rhodotorula laryngis and $\mathrm{Cr}$. victoriae. On the other hand, C. sake, D. fristingensis, G. antarctica and Sp. salmonicolor have been isolated only in the Southern Cone (South American glaciers and Antarctica). This work reports for the first time the isolation of Cryptococcus gastricus, Cryptococcus gilvescens, D. fristingensis and Leucosporidiella creatinivora from an Antarctic region. Also isolated was $W$. anomalus, which is not generally found in cold regions.

During molecular analysis of the yeasts, most isolates assigned to the same species possessed identical D1/D2 and ITS sequences. Thus, combining these rDNA regions is a useful technique for rapid identification and typing of yeasts, as others have suggested [14,20,21]. However, the isolates identified as Leuconeurospora $s p$. were $0.7 \%$ and $0.9 \%$ different in their D1/D2 (578 bp) and ITS (534 bp) sequences, respectively. Similarly, the isolates identified as $D$. fristingensis exhibited identical D1/D2 (456 bp) sequences, but their ITS (479 bp) sequences were markedly different (4.4\%), and their overlap was punctuated with several gaps. Furthermore, given the physiological differences between isolates that are identical or similar at molecular level, strongly support that the definitions of yeast species must be supplemented by classical characterizations.

Most yeast isolates showed lipase activity, consistent with a previous report in which all of the filamentous fungi from Antarctica displayed this activity [22]. Among the "cold loving" yeasts, lipase activity has been described in Pseudozyma antarctica [23], Leucosporidium antarcticum [24] and in species of Cryptococcus and Rhodotorula [25]. Unlike this last-mentioned study, we detected lipase activity in $R$. laryngis also. Lipase activity has also been described in W. anomalus from tropical environments [26]. The least common extracellular activity was xylanase, observed only in the D. fristingensis isolate. Although this activity has been previously described in Cryptococcus species [27,28], no xylanase activity was observed in the Cryptococcus isolates identified here. Consistent with our results, protease, amylase and esterase extracellular activities have been reported in several yeast species isolated from cold and tropical environments [24-26,29-33]. However, we present the first report of extracellular amylase activity in Le. creatinivora, $H$. watticus, Leuconeurospora sp. and D. fristingensis. In addition to Mrakia and Rhodotorula species, for which extracellular pectinase activity has been described [33], we detected pectinase activity in species of Wickerhamomyces, Metschnikowia, Dioszegia, Leucosporidiella and Candida. All Mrakia species isolated in this work showed cellulase activity, which has been previously described in Mrakia frigida isolated from King George Island [34]; furthermore, this activity was observed in Cryptococcus and Dioszegia species, contrary to a previous report [25]. Extracellular chitinase activity has been reported in Cryptococcus species [26], but here we observed this activity in M. psychrophila, Sp. salmonicolor, Metschnikowia sp., Leuconeurospora sp. and D. fristingensis. We detected cellulase and chitinase activities in yeasts species that have not been described from cold regions, probably because our sampling sites included areas with vegetation and animal contact and/or were located close to the sea. Cellulose is one of the most abundant carbohydrates produced by plants [35] and chitin is the most abundant renewable polymer in the ocean, where it constitutes an important source of carbon and nitrogen [36]. Furthermore, significant quantities of lipids exist in phytoplankton [37] and in sediments of this region [38], which can explain the high incidence of lipase activity found in the yeasts. All of the extracellular enzyme activities analyzed in this work are potentially useful to industry: amylases in food processing, fermentation and pharmaceutical industries; cellulases and pectinases in textiles, biofuel processing and clarification of fruit juice; esterase in the agro-food industries; lipases and proteases in food and beverage processing, detergent formulation and environmental bioremediations; chitinases in biocontrol and treatment of chitinous waste; xylanase as a hydrolysis agent in biofuel and solvent industries [10,39-41].

\section{Conclusions}

Similar to previous reports of microorganisms isolated from cold environments, the yeasts isolated in this work are predominately psychrotolerant. Rapid identification/ typing of yeasts was achieved through the use of D1/D2 and ITS regions; however, other physiological and biochemical tests are required for accurate species/strains definition. The diversity of extracellular enzyme activities in the yeasts, and hence the diversity of compounds that 
may be degraded/transformed, reflects the importance of the yeast community in nutrient recycling in the Antarctic regions. In addition, studies about the adaptation of the different yeast species to adverse conditions (temperature, freeze-thaw, UV radiation, nutrient availability, competence, etc.) could shade light on the evolution of molecular mechanisms (carbon metabolisms, cell wall and protein structure, etc.), which are implicated in facilitating that accommodation. As an example, changes in protein structure are fundamental to allow conformation of the cytoskeleton, enzyme activity, etc. The Antarctic yeast isolates may potentially benefit industrial processes that require a high enzymatic activity at low temperatures, including bread, baking, textile, food, biofuel and brewing industries.

\section{Methods}

\section{Sampling sites}

All sampling sites were located on King George Island $\left(62^{\circ} 02^{\prime} \mathrm{S} 58^{\circ} 21^{\prime} \mathrm{W} / 62.033^{\circ} \mathrm{S} 58.35^{\circ} \mathrm{W}\right)$, the major island of the Shetland South Archipelago (Figure 1). A total of 34 soil and 14 water samples were collected in January of 2009. The temperature and altitude of the sampling sites varied from 0 to $11.9^{\circ} \mathrm{C}$ and from 0 to $182 \mathrm{~m}$, respectively. For soil samples, sterile $50 \mathrm{ml}$ tubes were filled with soil, sealed and stored at $-20^{\circ} \mathrm{C}$. For water samples, $200-500 \mathrm{ml}$ of water were collected from terrestrial sources and processed in situ using the 55-PLUS ${ }^{\mathrm{TM}}$ MONITOR system (Millipore, Billerica, MA, USA,) with cellulose filter for yeasts and molds, as specified by the manufacturer. The dishes were then stored at $4^{\circ} \mathrm{C}$ until processing.

\section{Sample processing, yeast cultivation and isolation}

Five grams of each soil sample was suspended in $5 \mathrm{ml}$ of sterile water by vigorous agitation on a vortex for $10 \mathrm{~min}$. Following decantation of the coarse particulate material, $200 \mu \mathrm{l}$ of the suspension was seeded onto plates containing YM medium $(0.3 \%$ yeast extract, $0.3 \%$ malt extract, $0.5 \%$ peptone) supplemented with $2 \%$ glucose and $100 \mu \mathrm{g} / \mathrm{ml}$ chloramphenicol (YM-cm). The plates were incubated at $4,10,15$ and $22^{\circ} \mathrm{C}$. Duplicate of water sampling dishes were incubated at 4 and $10^{\circ} \mathrm{C}$. The plates were incubated for 3 months and periodically inspected for colony development. Once a colony became visible, it was immediately transferred to fresh YM-cm plates and incubated at the same temperature as the source-plate. The procedure was repeated for each soil sample to maximize the number of isolates.

Long-term preservation of the yeast isolates was achieved via two methods; the gelatin drop method $[42,43]$ and cryopreservation at $-80^{\circ} \mathrm{C}$ in $30 \%$ glycerol.

\section{Determination of growth temperatures and carbon source assimilation}

Yeast growth at different temperatures was assessed by a method based on comparison of colony sizes on solid media, which is applicable to the determination of minimum inhibitory concentration in yeasts [44]. The yeasts were seeded onto YM plates, incubated at 4, 10, 15, 22, 30 and $37^{\circ} \mathrm{C}$, and the colony sizes were recorded daily. For each yeast at each temperature, a plot of colony size vs. incubation time was constructed; the temperatures at which colony diameter increased significantly were considered as positive for growth, while the temperature at which the slope changed most rapidly was considered as the "best" or "optimal" for the growth. Glucose fermentation test were performed using a Durham tube. The assimilation of 29 different carbon sources was determined using the API ID 32C gallery (bioMérieux, Lyon, France) as specified by the manufacturer. Briefly, a colony portion was suspended in $400 \mu \mathrm{l}$ of sterile water. Following adjustment to $\mathrm{A}_{600 \mathrm{~nm}} \approx 0.5$ (equivalent to 2 McFarland standard), $250 \mu \mathrm{l}$ of the suspension was added to an ampule of api $\mathrm{C}$ medium. Each well of the strip was seeded with $135 \mu \mathrm{l}$ of this final suspension and incubated in a humid chamber. The turbidity $(+)$ or lack thereof $(-)$ in the wells was used as indicator of growth and was determined by visual inspection relative to the negative control well. A bionumber code was obtained from the data using the apiweb ${ }^{\mathrm{TM}}$ software.

\section{DNA extraction, amplification, sequencing and analysis}

$50 \mathrm{ml}$ of each yeast culture $\left(\mathrm{A}_{600 \mathrm{~nm}}=0.6\right.$ to 0.8$)$ was centrifuged at 7,000 x g for $10 \mathrm{~min}$, the pellet was suspended in $5 \mathrm{ml}$ of TE buffer and $300 \mu \mathrm{l}$ aliquots of the cellular suspension were mixed with $250 \mu \mathrm{l}$ of $0.5 \mathrm{~mm}$ diameter glass beads, vortexed for $10 \mathrm{~min}$ and centrifuged at $12,000 \times \mathrm{g}$ for $5 \mathrm{~min}$. The DNA was obtained from $300 \mu \mathrm{l}$ of the supernatant using the Wizard Genomic DNA Purification kit (Promega, Madison, USA) as specified by the manufacturer. The concentration and integrity of the DNA samples were analyzed by electrophoresis in $1.5 \%$ agarose gels. The D1/D2 and ITS15.8S-ITS2 regions of rDNA were amplified with the primers pairs F63/LR3 [45] and ITS1/ITS4 [46], respectively, using $\mathrm{Taq}$ polymerase (Fermentas International INC.) in thermal cyclers (Applied Biosystems). The resulting amplicons were separated by electrophoresis in $1.5 \%$ agarose gels immersed in TAE buffer containing ethidium bromide $(0.5 \mu \mathrm{g} / \mathrm{ml})$ and were purified from the gels as described in Boyle and Lew [47]. Most of the nucleotide sequences were determined using the sequencing service of Macrogen INC. In some cases, the DNA Sequencing Kit Dynamic Termination Cycle (Amersham Biosciences Limited) and a Genetic analyzer 3100 Avant automatic sequencer (Applied Biosystem) were used. 


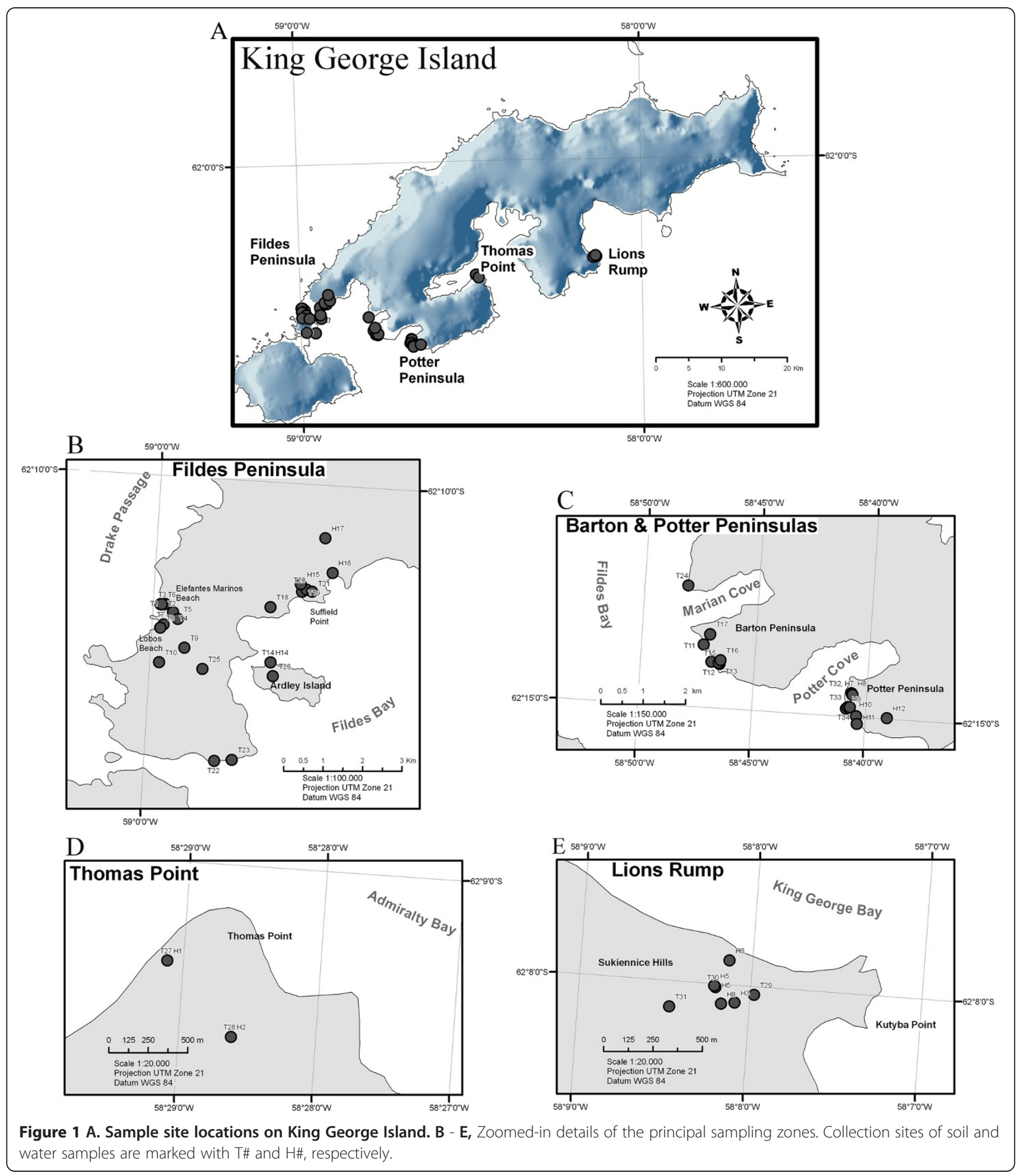

The sequences were analyzed using the Geneious Pro 5.4.5 software (Biomatters, Auckland, New Zealand).

\section{Extracellular enzyme activity assays}

All assays were performed on solid YM medium supplemented with $2 \%$ glucose (unless otherwise specified) and the appropriate substrate for enzyme activity. The plates were incubated at the optimal growth temperature of the individual yeast isolate, and the enzyme activities determined as described below.

Amylolytic activity. The cells were grown in medium containing $0.2 \%$ soluble starch. The plates were flooded 
with $1 \mathrm{ml}$ of iodine solution, and positive activity was defined as a clear halo around the colony on a purple background [48].

Cellulase activity. The cells were grown in medium supplemented with $0.5 \%$ carboxymethylcellulose [49]. The plates were flooded with $1 \mathrm{mg} / \mathrm{ml}$ of Congo red solution, which was poured off after $15 \mathrm{~min}$. The plates were then flooded with $1 \mathrm{M} \mathrm{NaCl}$ for $15 \mathrm{~min}$. Positive cellulase activity was defined as a clear halo around the colony on a red background [50].

Chitinase activity. The cells were grown in medium containing $2.5 \%$ purified chitin. Chitinase activity was indicated directly by the presence of a clear halo around the colony [48].

Lipase activity. The cells were grown in medium containing $1 \%$ tributyrin. Lipase activity was indicated by a clear halo around the colony [51].

Protease activity. The cells were grown in medium supplemented with $2 \%$ casein at $\mathrm{pH}$ 6.5. Protease activity was indicated by the presence of a white precipitate around the colony [49].

Xylanase activity. The cells were grown in medium supplemented with $0.5 \%$ xylan [52]. Xylanase activity was indicated by a clear halo around the colony. Pectinase activity. The cells were grown in $0.67 \%$ YNB medium, pH 7.0, containing 1\% pectin [26]. The plates were flooded with $1 \%$ hexadecyltrimethylammonium bromide, and activity was indicated by a clear halo around the colony on a red background [48]. Esterase activity. The cells were grown in medium composed of $1 \%$ bacto peptone, $0.5 \% \mathrm{NaCl}, 0.4 \%$ $\mathrm{CaCl}_{2} * 2 \mathrm{H}_{2} \mathrm{O}$ and $1 \%$ Tween 80 [53], and esterase activity was indicated by a white precipitate around the colony.

\section{Additional files}

Additional file 1: Molecular identification of yeast isolates obtained in this work. Summary of Blast search results obtained for D1/D2 and ITS1-5.8S-ITS2 rDNA sequences. The closets Blast-hits corresponding to uncultured yeasts were not considered.

Additional file 2: Colony morphology of Leuconeurospora sp. isolates. Yeasts were cultivated on YM plates supplemented with glucose. The isolates $\mathrm{T} 11 \mathrm{Cd} 2$ and $\mathrm{T} 27 \mathrm{Cd} 2$ possess identical D1/D2 and ITS sequences, yet are morphologically different.

Additional file 3: Carbon source assimilation by yeast isolates obtained in this work. Determinations were performed using the API ID $32 \mathrm{C}$ gallery (bioMérieux, Lyon, France) according to manufacturer/s instructions. Gal, D-galactose; Sac, D-sucrose; Nag, N-acetyl-glucosamine; Lat, lactic acid; Ara, L-arabinose; Cel, D-cellobiose; Raf, D-raffinose; Mal, maltose; Tre, D-trehalose; 2kg, 2-ketoglutamate; Mdg, Methyl-aDglucopiranoside; Man, D-mannitol; Lac, D-lactose; Ino, Inositol; Sor, D-sorbitol; Xyl, D-xylose; Rib, D- ribose; Gly, Gycerol; Rha, L-rhamnnose; Ple, pallatinose; Ery, erytritol; Mel, mellibiose; Grt, glucoronate; Mlz, D-mellicitose; Gnt, gluconate; Lvt, levulinic acid; Glu, D-glucose; Sbe, L-sorbose; Gln, glucosamine. +, assimilation; -, no assimilation. Determinations for each yeast were performed twice.

\section{Competing interests}

The authors declare that they have no competing interests.

\section{Authors' contributions}

MC, isolation and molecular characterization of yeasts; JMR, isolation and biochemical characterization of yeasts; SB, collection of water and soils samples; VC and JA, participated in the study design; MB conceived the study and participated in its design and coordination; and MB, JA and VC wrote the manuscript. All authors approved the final manuscript.

\section{Acknowledgements}

We thank Ricardo Jaña (Departamento Científico - Instituto Antártico Chileno) for compiling the maps. This work was supported by grant T_23-09 from the Instituto Antártico Chileno.

Received: 23 July 2012 Accepted: 30 October 2012

Published: 6 November 2012

\section{References}

1. Margesin R, Miteva V: Diversity and ecology of psychrophilic microorganisms. Res Microbiol 2011, 162:346-361.

2. Robinson $\mathrm{CH}$ : Cold adaptation in Arctic and Antarctic fungi. New Phytol 2001, 151:341-353.

3. Gounot AM: Psychrophilic and psychrotrophic microorganisms. Experientia 1986, 42:1192-1197.

4. D'Amico S, Collins T, Marx JC, Feller G, Gerday C: Psychrophilic microorganisms: challenges for life. EMBO reports 2006, 7:385-389.

5. Gerday C, Aittaleb M, Bentahir M, Chessa JP, Claverie P, Collins T, D'Amico S, Dumont J, Garsoux G, Georlette D: Cold-adapted enzymes: from fundamentals to biotechnology. Trends Biotechnol 2000, 18:103-107.

6. Margesin R, Feller G: Biotechnological applications of psychrophiles. Environ Technol 2010, 31:835-844.

7. Holdgate MW: Philosophical Transactions of the Royal Society of London B, Biological Sciences Philosophical Transactions of the Royal Society of London B1977, 2. Biological Sciences 1977, 279:5.

8. Smith VR: Climate change in the sub-Antarctic: an illustration from Marion Island. Clim Chang 2002, 52:345-357.

9. Menna ME: Yeasts from Antarctica. J Gen Microbiol 1960, 23:295-300

10. Buzzini P, Branda E, Goretti M, Turchetti B: Psychrophilic yeasts from worldwide glacial habitats: diversity, adaptation strategies and biotechnological potential. FEMS Microbiol Ecol 2012, 82:217-241.

11. Kutty SN, Philip R: Marine yeasts: a review. Yeast 2008, 25:465-483.

12. Vaz ABM, Rosa LH, Vieira MLA, Garcia $V$, Brandão LR, Teixeira LCR, Moliné M, Libkind D, van Broock M, Rosa CA: The diversity, extracellular enzymatic activities and photoprotective compounds of yeasts isolated in Antarctica. Braz J Microbiol 2011, 42:937-947.

13. Connell LB, Redman R, Rodriguez R, Barrett A, Iszard M, Fonseca A Dioszegia antarctica sp. nov. and Dioszegia cryoxerica sp. nov., psychrophilic basidiomycetous yeasts from polar desert soils in Antarctica. Int J Syst Evol Microbiol 2010, 60:1466-1472.

14. Kurtzman CP: Yeast species recognition from gene sequence analyses and other molecular methods. Mycoscience 2006, 47:65-71.

15. Horowitz NH, Cameron RE, Hubbard JS: Microbiology of the dry valleys of Antarctica. Advancement Of Science 1972, 176:242-245.

16. Convey $P$ : The influence of environmental characteristics on life history attributes of Antarctic terrestrial biota. Biol Rev 1996, 71:191-225.

17. Arnold RJ, Convey P, Hughes KA, Wynn-Williams DD: Seasonal periodicity of physical factors, inorganic nutrients and microalgae in Antarctic fellfields. Polar Biol 2003, 26:396-403.

18. Jeewon R, Hyde KD: Detection and diversity of fungi from environmental samples: traditional versus molecular approaches. Microbiology: Advanced Techniques in Soil; 2007:1-15.

19. Kurtzman CP, Fell JW, Boekhout T: The yeasts: a taxonomic study. Amsterdam: Elsevier Science Limited; 2011

20. Linton CJ, Borman AM, Cheung G, Holmes AD, Szekely A, Palmer MD, Bridge PD, Campbell CK, Johnson EM: Molecular identification of unusual pathogenic yeast isolates by large ribosomal subunit gene sequencing: 2 years of experience at the United kingdom mycology reference laboratory. J Clin Microbiol 2007, 45:1152-1158. 
21. Scorzetti G, Fell JW, Fonseca A, Statzell-Tallman A: Systematics of basidiomycetous yeasts: a comparison of large subunit D1/D2 and internal transcribed spacer rDNA regions. FEMS Yeast Res 2002, 2:495-517.

22. Fenice $M$, Selbmann $L$, Zucconi $L$, Onofri S: Production of extracellular enzymes by Antarctic fungal strains. Polar Biol 1997, 17:275-280.

23. Shivaji S, Prasad GS: Antarctic Yeasts: Biodiversity and Potential Applications. In Yeast Biotechnology: Diversity and Applications. Edited by Satyanarayana T, Kunze Gotthard (Eds.). Springer Publishers, Amsterdam: The Netherlands; 2009:pp3-18.

24. Turkiewicz M, Pazgier M, Kalinowska H, Bielecki S: A cold-adapted extracellular serine proteinase of the yeast Leucosporidium antarcticum. Extremophiles 2003, 7:435-442.

25. Brizzio S, Turchetti B, de Garcia V, Libkind D, Buzzini P, van Broock M Extracellular enzymatic activities of basidiomycetous yeasts isolated from glacial and subglacial waters of northwest Patagonia (Argentina). Can J Microbiol 2007, 53:519-525.

26. Buzzini P, Martini A: Extracellular enzymatic activity profiles in yeast and yeast-like strains isolated from tropical environments. J Appl Microbiol 2002, 93:1020-1025.

27. Amoresano A, Andolfo A, Corsaro MM, Zocchi I, Petrescu I, Gerday C, Marino G: Structural characterization of a xylanase from psychrophilic yeast by mass spectrometry. Glycobiology 2000, 10:451-458.

28. Gomes J, Gomes I, Steiner W: Thermolabile xylanase of the Antarctic yeast Cryptococcus adeliae: production and properties. Extremophiles 2000, 4:227-235.

29. Turchetti B, Buzzini P, Goretti M, Branda E, Diolaiuti G, D'Agata C, Smiraglia C, Vaughan-Martini A: Psychrophilic yeasts in glacial environments of Alpine glaciers. FEMS Microbiol Ecol 2008, 63:73-83.

30. Vishniac HS: Cryptococcus friedmannii, a new species of yeast from the Antarctic. Mycologia 1985, 77:149-153.

31. Ray MK, Devi KU, Kumar GS, Shivaji S: Extracellular protease from the antarctic yeast Candida humicola. Appl Environ Microbiol 1992, 58:1918-1923.

32. De Mot R, Verachtert $H$ : Purification and characterization of extracellular alpha-amylase and glucoamylase from the yeast Candida antarctica CBS 6678. Eur J Biochem 1987, 164:643-654.

33. Pathan AA, Bhadra B, Begum Z, Shivaji S: Diversity of yeasts from puddles in the vicinity of midre lovenbreen glacier, arctic and bioprospecting for enzymes and fatty acids. Curr Microbiol 2010, 60:307-314.

34. Krishnan A, Alias SA, Wong CMVL, Pang K-L, Convey P: Extracellular hydrolase enzyme production by soil fungi from King George Island, Antarctica. Polar Biol 2011, 34:1535-1542.

35. Kasana RC, Gulati A: Cellulases from psychrophilic microorganisms: a review. J Basic Microbiol 2011, 51:572-579.

36. Souza CP, Almeida BC, Colwell RR, Rivera IN: The importance of chitin in the marine environment. Mar Biotechnol (NY) 2011, 13:823-830.

37. Henderson RJ, Olsen RE, Eilertsen HC: Lipid composition of phytoplankton from the Barents Sea and environmental influences on the distribution pattern of carbon among photosynthetic end products. Polar research 1991, 10:229-238.

38. Fabiano M, Danovaro R: Meiofauna distribution and mesoscale variability in two sites of the Ross Sea (Antarctica) with contrasting food supply. Polar Biol 1999, 22:115-123.

39. Pulicherla KK, Ghosh M, Kumar PS, Sambasiva Rao KRS: Psychrozymes-The Next Generation Industrial Enzymes. J Marine Sci Res Development 2011, $1: 2$.

40. Aurilia V, Parracino A, D'Auria S: Microbial carbohydrate esterases in cold adapted environments. Gene 2008, 410:234-240.

41. Dahiya N, Tewari R, Hoondal GS: Biotechnological aspects of chitinolytic enzymes: a review. Appl Microbiol Biotechnol 2006, 71:773-782.

42. Baeza M, Retamales $P$, Sepulveda D, Lodato $P$, Jimenez $A$, Cifuentes V: Isolation, characterization and long term preservation of mutant strains of Xanthophyllomyces dendrorhous. J Basic Microbiol 2009, 49:135-141.

43. Marangon AV, Bertoni TA, Kioshima ES, Falleiros De Padua RA, Venturini S, Svidzinski Tl: Dehydrated gelatin drops: a good method for fungi maintenance and preservation. New Microbiol 2003, 26:305-309.

44. Xu J, Vilgalys R, Mitchell TG: Colony size can be used to determine the MIC of fluconazole for pathogenic yeasts. J Clin Microbiol 1998, 36:2383-2385

45. Fell JW, Boekhout T, Fonseca A, Scorzetti G, Statzell-Tallman A: Biodiversity and systematics of basidiomycetous yeasts as determined by large- subunit rDNA D1/D2 domain sequence analysis. Int J Syst Evol Microbio/ 2000, 50(Pt 3):1351-1371.

46. Fujita SI, Senda Y, Nakaguchi S, Hashimoto T: Multiplex PCR using internal transcribed spacer 1 and 2 regions for rapid detection and identification of yeast strains. J Clin Microbiol 2001, 39:3617-3622.

47. Boyle JS, Lew AM: An inexpensive alternative to glassmilk for DNA purification. Trends Genet 1995, 11:8.

48. Hankin L, Anagnostakis SL: The use of solid media for detection of enzyme production by fungi. Mycologia 1975, 67:597-607.

49. Strauss ML, Jolly NP, Lambrechts MG, van Rensburg P: Screening for the production of extracellular hydrolytic enzymes by non-Saccharomyces wine yeasts. J Appl Microbiol 2001, 91:182-190.

50. Teather RM, Wood PJ: Use of Congo red-polysaccharide interactions in enumeration and characterization of cellulolytic bacteria from the bovine rumen. Appl Environ Microbiol 1982, 43:777.

51. Gopinath SCB, Anbu P, Hilda A: Extracellular enzymatic activity profiles in fungi isolated from oil-rich environments. Mycoscience 2005, 46:119-126.

52. McCarthy AJ, Peace E, Broda P: Studies on the extracellular xylanase activity of some thermophilic actinomycetes. App/ Microbiol Biotechnol 1985, 21:238-244.

53. Slifkin M: Tween 80 opacity test responses of various Candida species. J Clin Microbiol 2000, 38:4626.

doi:10.1186/1471-2180-12-251

Cite this article as: Carrasco et al:: Diversity and extracellular enzymatic activities of yeasts isolated from King George Island, the sub-Antarctic region. BMC Microbiology 2012 12:251.

\section{Submit your next manuscript to BioMed Central and take full advantage of:}

- Convenient online submission

- Thorough peer review

- No space constraints or color figure charges

- Immediate publication on acceptance

- Inclusion in PubMed, CAS, Scopus and Google Scholar

- Research which is freely available for redistribution 